\title{
Modelling of solidification and heat treatment for the prediction of yield stress of cast alloys
}

\author{
Ch.-A. Gandin, Y. Bréchet, M. Rappaz, G. Canova, M. Ashby, H. Shercliff
}

\begin{abstract}
$\boldsymbol{A}$ model is developed for the prediction of the microstructure evolution of cast alloys during its industrial process route. The materials under consideration are binary aluminium-copper alloys. The process are casting, homogenising and ageing. A suite of models is built, which successively calculates microsegregation taking place during solidification and homogenisation, and precipitation occurring during ageing of the alloy. As a final output, the model permits the final yield stress of the material to be calculated as a function of the process parameters (i.e., casting cooling rate, inoculation of the alloy, duration and temperature of the homogenising and ageing heat treatments). This is made possible by introducing a structural hardening model between the diffusion driven phase transformation models and a final mechanical model for heterogeneous materials.
\end{abstract}

Parole chiave: fonderia, solidificazione, trattamenti termici

\section{PHASE TRANSFORMATION MODELS}

Modelling of solidification is based on the resolution of the solute conservation equation in spherical coordinates, coupled with a heat balance. The size of the spherical domain represents the average grain size. Since the dendritic nature of the grains is not accounted for, only the formation of "globulitic" grains is modelled, whose approximation by spheres is well justified. Such grain structure is often observed in aluminium casting alloys, a common industrial practice being to add into the melt very efficient inoculation particles. The resolution of the conservation equation accounts for diffusion in maximum three phases. For instance, the primary aluminium solid phase, $\alpha-\mathrm{Al}$, the liquid, 1 , and the secondary $\theta-\mathrm{Al}_{2} \mathrm{Cu}$ phase, are simultaneously present during the eutectic transformation according to Figure 1a. During cooling of the system from an initially liquid state, each new solid phase starts to form without nucleation undercooling once the uniform temperature domain reaches a new equilibrium temperature (i.e., either the liquidus or the eutectic temperature). The inputs of the model are thus the average grain size after solidification (equivalent to the final grain density), and the cooling rate during solidification imposed through a constant enthalpy change over time (Figure 1b). The outputs of the calculations are the evolution with time of the phase fractions as well as the evolution with time of the solute profile in the grain envelope at room temperature. Homogenisation is modelled using the same one-dimensional solute diffusion model developed for solidification. It is done by heating the system (through a positive enthalpy change over time) up to the desired homogenisation temperature, and by keeping the system at that temperature for a given time (Figure 1b). As a result, the $\theta-\mathrm{Al}_{2} \mathrm{Cu}$ phase is progressively dissolved, eventually disappears, and the concentration profile within the grain is flatten.

Modelling of precipitation is carried out by using the model first proposed by Langer and Schwartz [1] and modified by Kampmann and Wagner [2]. The model considers nucleation, growth and coarsening of the precipitates as concomitant processes. Rate equations are thus written and solved

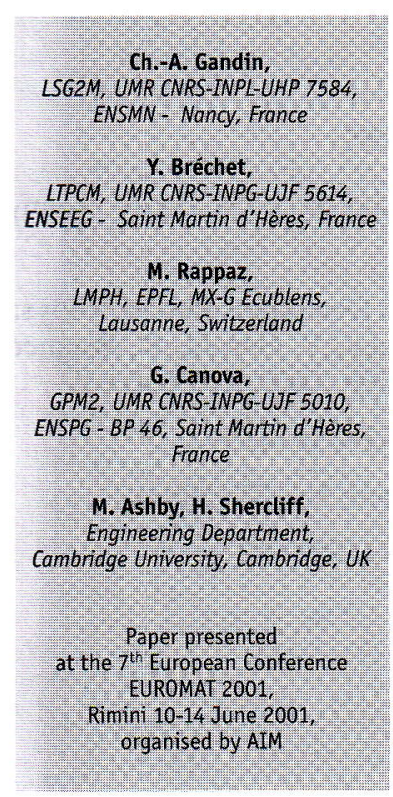

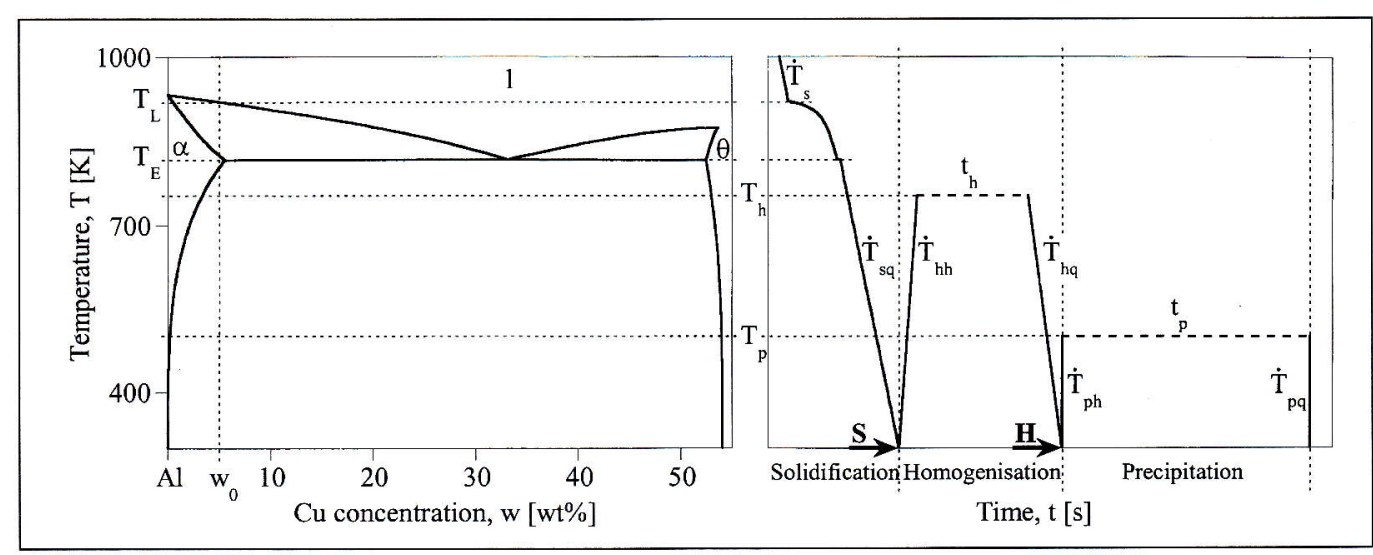

Figure 1 - (a) Aluminium-rich region of the binary Al-Cu phase diagram and (b) schematics of a typical temperature history for a cast alloy with structural hardening. The process parameters describing the heat treatments of a cast alloy are defined in $(b)$.

Figura 1 - (a) Regione del diagramma di fase binario di Al-Cu ricca di alluminio e (b) schema di temperature tipiche per una lega per getti con indurimento strutturale. I parametri di processo che descrivono i trattamenti termici di una lega per getti sono definiti in (b).

(1)




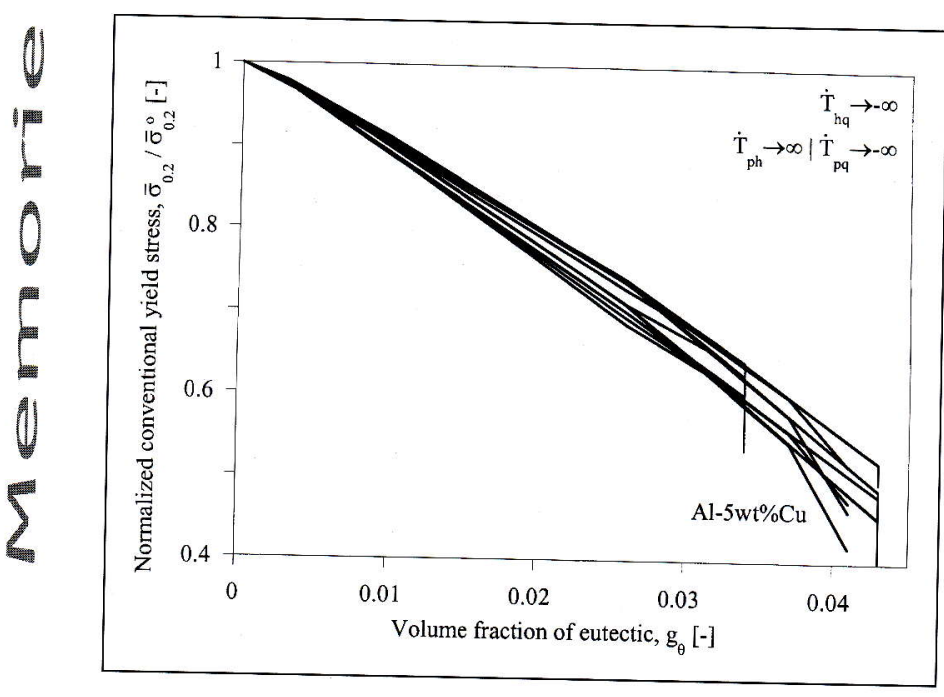

Figure 2 - Variation as a function of the residual eutectic fraction, $g_{\theta}$ of the normalized conventional yield stress of cast alloys, $\bar{\sigma}_{0.2}$ with respect to a perfectly homogenised and segregation free alloy (no eutectic phase left and no solute gradient), $\bar{\sigma}_{0.2}^{\circ}$. The standard alloy is defined by the alloy composition, Al-5wt\% $\%$, the average grain size of the $\alpha$-Al phase, $R_{g}=50 \mu m$, the solidification process parameters, $\dot{T}_{s}=-1 K \mathrm{~K}^{-1}, \dot{T}_{s q}=-1 \mathrm{Ks}^{-1}$, the homogenisation process parameters, $T_{h h}^{s}=3 K^{-1}, T_{h q}^{s q} \rightarrow-\infty, T_{h}=800 K, t_{h}=1 h$, and the ageing process parameters, $T_{p h} \rightarrow \infty$ and $\dot{T}_{p q} \rightarrow-\infty, T_{p}=500 \mathrm{~K}$ $t_{p}=1$ day. Individual variations considered for these parameters include $R_{g}=100 \mu \mathrm{m}, \dot{T}_{s}=-3 \mathrm{Ks}^{-1}, \dot{T}_{s q}=-3 \mathrm{Ks}^{-1}, T_{h}=750 \mathrm{~K}, t_{h}=10 \mathrm{~h}$, $T_{p}=400 K, t_{p}=10$ days. See Figure $1 \mathrm{~b}$ for the definition of the process parameters.

Figura 2 - Variazione in funzione della frazione eutettica residua, $g_{\theta^{\circ}}$ dello sforzo di snervamento convenzionale normalizzato di leghe fuse, $\bar{\sigma}_{0.2}$, rispetto ad una lega perfettamente omogeneizzata e priva di segregazioni (nessuna rimanente fase eutettica e nessun gradiente di soluto), $\bar{\sigma}_{0.2}^{\circ}$. La lega standard è definita da composizione della lega, Al-5wt\% Cu, dimensione media del grano della fase $\alpha-A l, R_{g}=50 \mu \mathrm{m}$, parametri del processo di solidificazione, $\dot{T}_{s}^{g}=-1 K \mathrm{~K}^{-1}, \dot{T}_{s q}=-1 K \mathrm{~s}^{-1}$, parametri del processo di omogeneizzazione, $\dot{T}_{h h}=3 \mathrm{Ks}^{-1}$, $\dot{T}_{h q} \rightarrow-\infty, T_{h}=800 \mathrm{~K}, t_{h}=1 \mathrm{~h}, e$ parametri del processo di invecchiamento, $T_{p h} \rightarrow \infty e \dot{T}_{p q} \rightarrow-\infty$ $T_{p}=500 \mathrm{~K}, t_{p}=1$ giorno. Le variazioni individuali considerate per questi parametri comprendono $R_{g}=100 \mu \mathrm{m}, \dot{T}_{s}=-3 \mathrm{Ks}^{-1}, \dot{T}_{s q}=-3 \mathrm{Ks}^{-1}$, $T_{h}=750 \mathrm{~K}, t_{h}=10 \mathrm{~h}, T_{p}=400 \mathrm{~K}, t_{p}=10$ giorni. Si veda la figura $1 \mathrm{~b} \mathrm{per}$ la definizione dei parametri di processo.

using a Runge-Kutta algorithm. As a result of the calculation, the size and volume fraction of the precipitates are determined at each radial position within the spherical grain as a function of the local composition and for a given artificial ageing temperature (Figure $1 b$ ).

\section{MECHANICAL MOOELS}

From the output of the phase transformation models, the structural hardening model developed by Deschamps [3] is used. It accounts for the volumetric fraction and for the size of the precipitates, as well as for the remaining solute content of the matrix. The flow stress is thus calculated as a function of the interaction of the dislocations with the precipitates, accounting for the transition occurring between the shearing and the Orowan mechanisms, as well as for solid solution strengthening. The model is applied at different location within the grain to deduce the space dependence of the flow stress, $\sigma_{\mathrm{y}}(\mathrm{r})$.

Finally, the global yield stress of the material is deduced from a mechanical model developed by Hervé and Zaoui [4] for a heterogeneous material. The model is based on a selfconsistent Eshelby-type approach and is extended to a material made of spherical embedded layers. Each layer is characterized by individual mechanical properties computed by the structural hardening model.

\section{RESULTS}

The main results of the model are summarised in Figure 2. For a given alloy composition, with different combinations of the process parameters (see figure caption for the list of the parameters investigated, as well as the magnitude of their variations), it is found that the variation of the yield stress of the alloy is a direct function of the residual eutectic fraction. This simple final result deduced from several calculations is consistent with the usual industrial practices. In order to optimise the yield stress of cast alloys, the process parameters are adjusted so as to maximise the solute content of the $\alpha$-Al solid solution. In turn, this practice corresponds to a minimisation of the residual eutectic fraction.

\section{CONCLUSION}

All the unit models are grouped into a single integrated model which describes the microstructure change of aluminium-copper alloys during its process route, and its effect on the final yield stress. The model is now completed and has been used to calculate the combined effect of inoculation, cooling rate, temperature and time of the homogenising and ageing treatments. Such predictions are sound since they include an intermediate calibration procedure of the model parameters based on experimental hardness measured by Hardy in homogenised aluminium-copper alloys. Thus, the model establishes direct links between the main process parameters of cast alloys and its final yield stress.

\section{ACKNOWLEDGEMENTS}

The authors would like to warmly acknowledge the Körber Foundation and the Ecole Polytechnique Fédérale de Lausanne for their financial supports.

\section{REFERENCES} 1) J. S. Langer and A. J. Schwartz, Phys. Rev. A21 (1980)
948.

2) R. Kampmann and R. Wagner, Decomposition of Alloys: the early stages. Eds. P. Haasen, V. Gerold, R. Wagner and M. F. Ashby, Pergamon Press, Oxford (1984) 91.

3) A. Deschamps, PhD Thesis. INPG (F) (1992).

4) E. Hervé and Zaoui, Int. J. Engng Sci. 31 (1993) 1.

5) H. K. Hardy, J. Inst. Metals 79 (1951) 321. 
MODELLISTICA DELLA SOLIDIFICAZIONE E DEL TRATTAMENTO TERMICO

PER LA PREVISIONE DELLO SFORZO DI SNERVAMENTO DI LEGHE PER GETI

E' stato sviluppato un modello per la previsione dell'evoluzione della microstruttura di leghe per getti durante il processo industriale. I materiali presi in esame sono leghe binarie alluminio-rame. Il processo consiste in colata, omogeneizzazione ed invecchiamento. E' stato costruito un modello, per il successivo calcolo delle microsegregazioni durante solidificazione e omogeneizzazione e della precipitazione durante l'invecchiamento della lega.

Il modello ha consentito di calcolare la tensione di snervamento finale del materiale in funzione dei parametri di processo (velocità di raffreddamento della colata, inoculazione della lega, durata e temperatura di trattamenti termici, omogenizzazione ed invecchiamento). Ciò è stato possibile mediante l'introduzione di un modello $d^{\prime}$ indurimento strutturale fra $i$ modelli di trasformazione di fase indotta dalla diffusione e un modello meccanico finale per i materiali eterogenei.

I risultati principali del modello sono ricapitolati nella figura 2.

Per una certa composizione della lega, con diverse combi- nazioni dei parametri di processo (si veda didascalia della figura per la lista dei parametri studiati, e dell'ampiezza delle loro variazioni), si è osservato che la variazione della tensione di snervamento della lega è una funzione diretta della frazione eutettica residua. Questo semplice risultato finale dedotto da diversi calcoli è coerente alle normali pratiche industriali. Per ottimizzare il carico di snervamento delle leghe fuse, $i$ parametri trattati sono stati regolati in modo da massimizzare il contenuto di soluto della soluzione solida $\alpha$-Al. Inoltre, questa pratica corrisponde ad una minimizzazione della frazione eutettica residua.

Tutti questi modelli sono rággruppati in un singolo modello integrato che descrive il cambiamento microstrutturale delle leghe di alluminio-rame durante il relativo processo ed effetto sulla tensione di snervamento finale. Il modello cosi' completato è stato utilizzato per calcolare $l$ effetto congiunto di inoculazione, velocità di raffreddamento, temperatura e tempo dei trattamenti di omogenizzazione ed invecchiamento. Tali previsioni sono attendibili poiché includono una procedura intermedia di calibratura dei parametri di modello basati su durezze sperimentali misurate da Hardy in leghe di alluminio-rame omogeneizzate. Quindi, il modello stabilisce collegamenti diretti fra i principali parametri di processo delle leghe per getti e i relativi carichi di snervamento finale. 